\title{
Regulações centrais, práticas regionais: a provisão dos oficiais de correio na América Portuguesa
}

\author{
Central Regulations, Regional Practices: \\ The Postal Officers of Portuguese America
}

Mayra Guapindaia*

\section{Resumo}

Até 1797, o direito de transportar cartas e auferir os lucros referentes ao serviço pertencia à família Gomes da Mata, detentora dos ofícios de Correio-mor do Reino e das Cartas de Mar. Foi naquele ano que os ofícios foram reincorporados e os serviços postais passaram para a alçada direta da Coroa. Essas reformas postais foram estendidas para a América Portuguesa e uma série de normas orientou a inauguração, nas vilas e cidades das capitanias, de Administrações de correio. Regionalmente, era papel das Juntas da Real Fazenda escolher e prover oficiais para realizar o trabalho cotidiano das administrações postais. Tendo em vista o surgimento desse novo posto administrativo e fazendário, este artigo tem o intuito de discutir como se deu o provimento dos Administradores de correio pelas Juntas da Real Fazenda.

Palavras-chave: reformas postais; administradores de correio; Juntas da Real Fazenda.

\section{Abstract}

Until 1797, the right to carry letters and to obtain profits related to the service belonged to the Gomes da Mata family, holder of the office of General Postmaster of the Kingdom and Overseas. It was on this year that the office was reincorporated, and postal services went to the Crown's direct authority. These postal reforms were extended to Portuguese America, and a series of rules guided the inauguration, in the villages and cities of the captaincies, of Post Office administrations. Regionally, it was the role of the Royal Financial Boards to choose and provide officers to carry out the daily work of the postal administrations. Taking into consideration the emergence of this new administrative and finance office, this article aims to discuss how the Administrators of the Post Offices were provided by the Royal Finance Boards. Keywords: postal reforms; postal administrations; Royal Finance Boards.

\footnotetext{
* Universidade de Lisboa (UL), Lisboa, Portugal. mayra.guapindaia@gmail.com <https://orcid. org/0000-0002-5438-894X>
} 
Até 1798, o sistema de correios da Monarquia portuguesa seguiu um modelo específico: o direito de transportar cartas e recolher as taxas referentes ao serviço estavam nas mãos da família Gomes da Mata que, por meio de um processo de compra, possuia os ofícios de Correio-mor do Reino e das cartas de Mar desde o século XVII. Em 1797 essa estrutura foi extinta e o Correio foi reincorporado à alçada direta da Coroa. No lugar do antigo sistema, surgiu outro, no qual a circulação de cartas seria controlada por uma administração centralizada.

A reforma dos correios fez parte de um conjunto amplo de ações administrativas do Ministro da Marinha e Ultramar, D. Rodrigo de Sousa Coutinho. O objetivo era recuperar a economia de Portugal, que se encontrava desgastada devido aos dispêndios da guerra com a França (Cardoso, 2001, p. 78). Inspirado por alguns pontos do liberalismo econômico de Adam Smith, as medidas de D. Rodrigo voltaram-se para a fiscalidade. Uma das principais metas era buscar alternativas à recolha tributária da Coroa, recorrendo-se a um tipo de taxação à riqueza não produtiva (Aidar, 2011, p. 150). Uma delas era a taxa cobrada pela entrega das cartas, denominada "porte". Segundo D. Rodrigo, o sistema postal desempenharia papel triplo: encurtaria o tempo da comunicação administrativa, promoveria o comércio e seria fonte de renda para o Erário Régio.

As reformas de correio atingiram a América Portuguesa. O Alvará de 20 de janeiro de 1798 indicava que o estabelecimento dos correios nas capitanias cabia às Juntas da Real Fazenda. Também foram lançadas normas específicas para as Juntas, especificando seu papel no provimento dos oficiais de correio. ${ }^{1}$ Portanto, surgiu a necessidade de se prover um novo quadro de oficiais, até então inexistentes em solo americano, para organizar o recebimento e despacho de cartas.

O tema dos correios, do ponto de vista de gestão administrativa, dialoga diretamente com a historiografia recente que busca compreender as transformações no oficialato régio a partir da segunda metade do século XVIII (Monteiro, 2009; Subtil, 2012; Stumpf, 2018). Por outro lado, também está ligado aos estudos da organização fazendária e da fiscalidade no Império Português (Aidar, 2011; Barcelos, 2014; Chaves, 2013; Costa \& Miranda, 2010). Contudo, apesar de inúmeras investigações na área, que focam nos oficiais de fazenda, os empregados de correio ainda não foram abordados de maneira sistemática. Logo, a discussão sobre as reformas de correio e o provimento de oficiais é um tema frutífero para compreender, a partir desse caso específico, o funcionamento da administração da Coroa Portuguesa em fins do século XVIII e início do XIX. 
A reforma do sistema postal atrela-se à crítica acerca da concessão de cargos e ofícios na Monarquia Portuguesa, uma vez que o serviço se encontrava patrimonializado por uma família. Tal posicionamento se insere em discussão iniciada no século XVIII e continuada na geração posterior, sobre a reprovação de doação de ofícios em propriedade vitalícia e hereditária e da necessidade de seleção de oficiais pelo mérito. Nesse sentido, o Regimento de 23 de novembro de 1770 buscou dar fim ao direito de hereditariedade dos ofícios, modificando a lógica da patrimonialização destes (Stumpf, 2018, p. 347). Contudo, apesar das críticas, os Gomes da Mata continuaram atuantes no ofício de Correio-mor durante todo o Período Pombalino.

Mudanças nesse sentido só ocorreram mais tardiamente. O Correio-mor foi condenado por D. Rodrigo de Sousa Coutinho por ser patrimônio de uma família quando, na concepção do Ministro, os serviços postais deveriam ser organizados diretamente pela Coroa para assim haver a recolha dos lucros do serviço. Em reflexões de 1786, muitos anos antes de sua passagem pela Secretaria da Marinha e Ultramar (1796-1801), D. Rodrigo fez uma severa crítica ao sistema de arrecadação e aos impostos vigentes em Portugal. Ele então apontava a necessidade de alteração de grande parte das taxas existentes e de meios para tornar a cobrança mais clara e objetiva (Coutinho, 1993, p. 234). Nesse sentido, a reestruturação da administração postal atingiu não só o Correio-mor, mas também os ofícios menores ligados às comunicações a distância.

Contudo, não se deve confundir esse processo com o surgimento de uma burocracia de Estado, no sentido weberiano do termo, entendida como um corpo de funcionários especializados e sem privilégios de nascimento. As lógicas de Antigo Regime continuaram atuantes até o século XIX. A existência de cargos públicos, no sentido estrito do termo, só existiu no Brasil após o período Vargas (Lopes, 2012). Portanto, deve-se levar em consideração outras lógicas, mais ligadas a concepções anteriores ao Estado Racional, que estavam por trás do Regimento de 1770 e da organização administrativa posterior a esta norma. Por parte dos vassalos, solicitações características do Antigo Regime, como pedidos de ocupação de ofícios por familiares após a morte, nunca cessaram de existir (Stumpf, 2014, p. 626). A Coroa tampouco, deixou de doar ofícios em propriedade. Por fim, a escolha de determinados indivíduos já enraizados na elite administrativa local também continuou ao longo desse período, o que revela a existência de uma lógica clientelar que perpassa o período da Independência (Cunha, 2007).

Tendo em vista que todas essas transformações e permanências situam-se no momento imediatamente anterior às reformas de correio e do surgimento 
de um novo tipo de oficial - os Administradores -, é de fundamental importância englobar este caso nas recentes discussões historiográficas acerca do provimento de empregados no serviço administrativo das capitanias nos últimos anos do século XVIII.

Assim, o objetivo deste artigo é compreender como foram implementadas as novas administações de correio da América Portuguesa, a partir da análise de um ponto específico: o provimento dos Administradores de correio. Parte-se da hipótese que, embora as Juntas da Fazenda buscassem seguir as normas lançadas pela Coroa, também se utilizavam da liberdade dada por elas para escolher oficiais que já estavam enraizados na estrutura administrativa de cada capitania. Isso contribuiu para a aceitação desses novos oficiais por grupos sociais importantes, como, por exemplo, os homens de negócio.

\section{AS ADMINISTRAÇÕES DE CORREIO ENTRE CENTRALIZAÇÃO E DESCENTRALIZAÇÃO}

As normas lançadas a partir de 1798 esboçaram a estrutura administrativa que os correios, tanto do Reino quanto da América Portuguesa, deveriam seguir. Elas são consequência das discussões acontecidas nos anos anteriores no sistema de comunicações a distância. O pensamento e as ações reformistas dos anos 1790 resultaram em transformações na forma de conceber os correios, que passou a ser considerada prerrogativa da Coroa.

Contudo, apesar das mudanças, a nascente estrutura administrativa dos correios continuou calcada em formas organizacionais do Antigo Regime. Por mais que ligada a ideais reformistas, as administrações de correios da América Portuguesa compartilhavam do antigo paradigma, pois a seleção de seus oficiais era feita levando em consideração, afora as qualidades técnicas necessárias para o desempenho da função, o enraizamento nas redes administrativas das capitanias. Era, portanto, um espaço em que poderia ser desenvolvido com maior autonomia o poder local.

Compreender essa descentralização significa voltar-se para a cadeia hierárquica relacionada aos correios das vilas e cidades. Cada Administração criada na esfera municipal respondia diretamente às Juntas da Real Fazenda. A decisão da inauguração de novas administrações e contratação de oficiais também pertenceria primordialmente a essas instituições. E o envolvimento das juntas das capitanias ocorreu de fato, conforme se pode constatar pela correspondência trocada entre os governadores de Rio de Janeiro, Minas Gerais, 
Goiás, Mato Grosso e Pará e posteriormente enviada à Secretaria da Marinha e Ultramar. ${ }^{2}$

A subordinação das administrações postais às Juntas da Fazenda é fruto da associação dos assuntos postais à estrutura fazendária da Coroa. As cartas passaram a ser entendidas como gênero passível de cobrança de taxa (o porte), ligado a recolha fiscal. Esse entendimento se reflete nas atribuições dos Administradores de correio especificadas nas "Instruções para os Correios da América”. Receber as cartas, contá-las, pesá-las e calcular o porte era parte do cotidiano administrativo desses empregados. Era rotineira também a prestação de contas às Juntas da Fazenda e, uma vez ao ano, ao Erário Régio. ${ }^{3}$ Por isso, é necessário entender a organização das Juntas da Fazenda para melhor matizar sua relação com as administrações de correio.

As Juntas da Fazenda eram órgãos de administração fazendária regionais criados durante o Período Pombalino. Sua função era administrar a arrecadação das capitanias, quer de forma direta, quer por meio de contratos. Os rendimentos arrecadados por elas eram utilizados para o provimento das folhas eclesiástica, civil e militar. As Juntas também tinham caráter de tribunal e competia a elas o julgamento contencioso das questões fazendárias (Chaves, 2013, p. 89).

As datas de criação destas instituições variam, mas iniciam-se por volta de 1760, sendo algumas anteriores à criação do Erário Régio, em 1761. As da Bahia e do Rio de Janeiro, por exemplo, datam de 1760. Portanto, as Juntas iniciam sua trajetória como um projeto de reforma fiscal paralelo àquele que acontecia no Reino. Aos poucos, contudo, o Erário tomou para si a fiscalização das Juntas, sendo que a maioria foi reestruturada por este órgão nos anos 1770 (Aidar, p. 172-173).

De acordo com Roberta Stumpf (2017, p. 152), essas instituições tinham como objetivo aumentar o controle dos oficiais fazendários pela Coroa. Uma das formas de garantir isso foi instituir os governadores como presidentes das Juntas, ou seja, um oficial nomeado pelo Rei. Contudo, o paradigma de descentralização e distribuição do poder para as instâncias locais não deixaram de atuar nesse momento. As Juntas podiam, segundo as próprias normas da Coroa, prover alguns de seus oficiais localmente e arrematar contratos que antes iam a leilão no Reino. Isso contribuiu para que houvesse uma maior autonomia tanto fiscal quanto administrativa nas capitanias.

As discussões historiográficas recentes ressaltam o fato de a característica descentralizada das Juntas ter aberto espaço para a autonomia de decisão local, permitindo a construção de uma elite fazendária que muitas vezes tomava 
decisões de acordo com interesses próprios, contrários às demandas centrais (Chaves, 2013, p. 84). Contudo, a relação entre Erário Régio e seus órgãos periféricos é mais complexa do que deixa entrever. Por exemplo, Alexandre Cunha aponta que, no caso específico da diminuição das arrecadações provenientes do ouro, a Junta da Fazenda de Minas Gerais tendeu a acatar as soluções embasadas pelo Erário Régio. Os oficiais das Minas, assim como os do Reino, ligavam a decadência do ouro ao contrabando, e não ao esgotamento natural do metal. Esse diálogo entre os dois polos permite perceber como, muitas vezes, a visão do centro se alastrava para a administração periférica (Cunha, 2007, p. 203).

Essa aparente contradição, que na verdade era uma característica da organização administrativa da época, encontra eco na questão dos correios. Assim, as reformas de correio podem ser consideradas um movimento decorrente de uma inciativa central e uniformizadora, uma vez que suas diretrizes e normas foram ditadas pela Coroa e se destinavam a ter uma aplicação geral. Contudo, pode-se perceber que houve, incentivada pelas próprias normas régias, uma dinâmica no sentido oposto a este, ou seja, a descentralização dos provimentos dos oficiais e da montagem da estrutura administrativa nas mãos das Juntas da Fazenda. Essa composição certamente abriu oportunidades para arranjos regionais, construídos a partir das possibilidades abertas pelas próprias normas. Isso não significa, contudo, que esses agentes atuavam em total desacordo com os interesses do centro. Afinal, a própria criação dos correios nas capitanias foi uma forma da Coroa de tentar gerir uma instância administrativa que até então funcionava sem normatizações centrais: as comunicações a distância.

As administrações de correio criadas nas vilas e cidades eram subordinadas às Juntas da Fazenda e, a partir delas, ao Erário Régio. Ao contrário do que ocorreu em Portugal, não foi criada uma Administração Central que subordinava as locais. ${ }^{4}$ Tal organização, embora tenha sofrido algumas modificações, permaneceu inalterada até pelo menos 1829, quando, após a Independência, surgiu um novo e muito mais complexo sistema de correios, contando com uma administração centralizada no Rio de Janeiro (Castro, 2016). Mesmo a mudança da Corte para o Rio de Janeiro em 1808 não deu fim às antigas práticas, pois as estruturas postais foram alteradas apenas de forma pontual e regionalizada. A preocupação da Coroa após o enraizamento na América parece ter-se voltado muito mais à abertura de caminhos e novos giros de correio do que à reorganização administrativa do sistema postal. ${ }^{5}$ Manteve-se a ten- 
dência de regionalização de correios das capitanias, com o espaço decisório circunscrito na jurisdição das Juntas da Fazenda.

Tal falta de unidade não é característica somente da organização dos correios. A criação do Brasil enquanto corpo homogêneo, quer jurídico, quer territorial, esteve associado ao processo de independência e à formação da Constituição. Antes, a administração do território estava dividida em uma multiplicidade de poderes, não havendo qualquer pretenção de criação de homogeneidade. Esse quadro só começou a ser paulatinamente modificado a partir da Revolução Liberal do Porto em 1820 (Slemian, 2006, p. 44-45).

Ou seja, a própria necessidade da Coroa de se conectar com o restante do território não era acompanhada, até os anos 1820, pela necessidade de formas de administração centralizadas. A liberdade de órgãos de poder regionais, como as Juntas da Fazenda, continuou sendo mantida. Assim, apesar dos esforços da Monarquia em conectar-se com os diversos territórios, facilitando as vias de acesso e comunicação, administrativamente, as capitanias continuavam a não formar um espaço integrado. Em 1808, os governadores continuaram a agir de acordo com as circunstâncias regionais, não servindo de "bons elos ou unidades entre as várias regiões da colônia” (Dias, 2005, p. 35). Nesse sentido, a relação entre as capitanias e o centro do poder pouco se modificou, pois continuou a ser feita de forma desagregada, sem sentido de unidade.

Essa inexistência de vínculos refletiu-se nas normas sobre correios lançadas após 1808. Mesmo com a transferência da sede do poder, não houve preocupação de organizar uma estrutura de correios centralizada, com sede no Rio de Janeiro, que subordinasse as outras administrações das capitanias. Na realidade, foram lançadas diversas normas pelo centro da Monarquia que apresentavam modificações pontuais nos sistemas de correios regionais.

Apesar de o correio do Rio de Janeiro ter mudado seu nome para Administração Geral e ter sido subordinado diretamente ao Erário Régio, o novo regulamento englobou medidas somente no que concerne ao sistema postal da Corte, não havendo menção de qualquer sujeição dos correios das outras capitanias à sede do governo. ${ }^{6}$ A utilização da nomenclatura Administração Geral é elucidativa por ser similar àquela utilizada em Lisboa. A adoção desse nome provavelmente vem da tentativa de transplantar a instituição lisboeta em solo americano, processo que ocorreu deliberadamente com vários outros órgãos administrativos a partir de 1808 (Stumpf, 2018, p. 340). Mas a denominação de Geral não pode ser vista como símbolo de criação de um sistema postal unificado, no qual a sede se encontrava no Rio de Janeiro. Com exceção do caso do Rio de Janeiro, as Juntas da Fazenda continuavam a possuir auto- 
nomia para nomear os oficiais e gerir as administrações. Assim, cabe elucidar quais foram os impactos dessa liberdade na provisão dos oficiais de correio.

\section{O PROVIMENTO DOS OFICIAIS DE CORREIO \\ PELAS JUNTAS DA REAL FAZENDA (1798-1821)}

O provimento dos ofícios de correio, por ser atribuição das Juntas da Real Fazenda, contribuiu para a autonomia das administrações postais e, indiretamente, para a aceitação da nova instituição pelas elites locais. Isso porque a escolha dos oficiais era feita entre indivíduos já conhecidos, detentores de outros ofícios fazendários, e por isso considerados, em uma lógica típica do Antigo Regime, como socialmente confiáveis. Esse processo é oposto ao que aconteceu na época dos Assistentes de Correio-mor da América Portuguesa em fins do século XVII e início do XVIII que, por serem nomeados pelo Correio-mor, despertavam desconfiança por parte dos grupos mercantis (Salvino, 2018, p. 189-205).

A questão da provisão de ofícios no Império Português deve ser discutida à luz dos conceitos relacionados à sociedade corporativa e aos entendimentos sobre a lógica da mercê no Antigo Regime português. A ocupação de cargos e ofícios das monarquias ibéricas estava de acordo com o funcionamento mais alargado da dinâmica social, na qual a provisão nesses postos seguia preceitos clientelares. Ou seja, para ser provido em determinados ofícios, importava não só o conhecimento técnico a respeito da função a ser desempenhada, mas também questões como amizade, parentesco e reciprocidade. Entrava em prática, portanto, a economia moral do dom que abarcava toda a sociedade, culminando por fim na figura régia (Bicalho, 1998).

A distribuição de ofícios era pautada pelos conceitos de liberalidade régia e justiça distributiva. A liberalidade era uma das principais justificativas do poder real, e as mercês eram feitas aos vassalos como forma de os reis se manterem no poder. A capacidade real de dar era uma das formas de cumprir o principal papel do Rei, o qual era a garantia da justiça e, consequentemente, da ordem e da paz (Olival, 2001, p. 20).

Em Portugal, as mercês podiam ser classificadas em dois grupos: provindas da liberalidade, ou seja, sem função remuneratória; e as mercês dadas para recompensar os serviços prestados, sendo por isso consideradas meio de remuneração. Em especial as últimas foram fator estruturante de toda a sociedade da época, que sempre buscava ascensão e inserção nos meios de poder a 
partir da lógica da recompensa. De fato, a busca por servir ao Rei como forma de ascensão social atingia não só as camadas aristocráticas como também grupos mais baixos (Idem, p. 21). Esta lógica da concessão de ofícios pela mercê, especialmente voltada para a questão do merecimento dos indivíduos, não será quebrada durante todo o Antigo Regime, alastrando-se inclusive para o século XIX, conforme é possível perceber no caso do provimento dos oficiais de correio.

Essa é uma chave explicativa ao fato de não se ter encontrado, entre as fontes levantadas nesta investigação, petições dos poderes locais contra os Administradores ou demais oficiais de correio. Ao contrário, estes empregados contavam com a consideração positiva dos homens de negócio. Exemplo disso é o requerimento do oficial de correio Daniel Nunes de Montes à Coroa visando aumento de ordenado, no qual consta um atestado dos negociantes da capitania acerca dos bons serviços prestados no serviço postal. ${ }^{7}$ Por meio de casos como este, é possível perceber que esses novos agentes estavam inseridos nas redes de sociabilidade dos territórios onde residiam. Portanto, é importante investigar a especificidade dos provimentos desses agentes de correio à luz das discussões historiográficas e das fontes encontradas, e como isso contribuiu para a autonomia de cada administração e para o enraizamento e reprodução dos grupos pertencentes às elites locais.

Segundo Roberta Stumpf (2014, p. 614), os cargos e ofícios no Antigo Regime eram de dois tipos, de acordo com seus provimentos: de concessão precária, ou seja, temporária (em serventia) ou de concessão vitalícia e, também, potencialmente hereditária (em propriedade). No Antigo Regime, a concessão em propriedade vitalícia era uma das formas de o monarca retribuir seus súditos pela prestação de serviços. Contudo, a partir do reinado de D. João V, e especialmente no Período Pombalino, houve grande desaprovação do sistema de patrimonialização dos ofícios. O Regimento com força de Lei de 23 de novembro de 1770 é o marco dessas críticas. Buscava-se, então, retomar o provimento baseado na "indústria pessoal", ou seja, os oficiais deveriam ser escolhidos de acordo com suas capacidades para desempenhar a função (Stumpf, 2016, p. 122).

Mas talvez o principal interesse pelo fim da patrimonialização fosse outro, ligado a questões financeiras. A concessão precária permitia que, ao fim do tempo de exercício, os ofícios retornassem às mãos da Coroa, podendo ser utilizados para novas remunerações a outros vassalos. Nesse período, sobretudo para os cargos intermédios da América portuguesa, foi comum a venda em serventia, ou seja, para desempenhar a função em período determinado, 
mediante o pagamento de donativo (Stumpf, 2012, p. 249). Essa política continuou sendo utilizada ao longo do século XIX, inclusive após a transferência da Corte para o Rio de Janeiro (Stumpf, 2018, p. 358-363).

É necessário refletir como essa lógica moldou o provimento dos ofícios de correio. A reincorporação do Correio-mor foi pautada pelo entendimento de que esse ofício, principal da Coroa, não deveria ser patrimônio de uma família, e sim controlado diretamente pelo Erário Régio. Mas até que ponto este mesmo entendimento se alastrou para os ofícios de correio menores? É crucial também indagar se o provimento feito pelas Juntas da Fazenda, e confirmados somente posteriormente pelo monarca, desempenharam algum papel na aceitação da nascente instituição e de seus funcionários em meio aos poderes locais. Além disso, importa tentar perceber quais atributos estavam atrelados às escolhas destes oficiais.

Primeiramente, cabem algumas reflexões a respeito dos conhecimentos contábeis e a nova estrutura dos correios. O domínio da escrituração mercantil e do sistema de partidas dobradas foi um pré-requisito adotado no período pombalino para o recrutamento de oficiais fazendários. ${ }^{8}$ Contudo, tais métodos ainda eram pouco utilizados no comércio português. Como solução para isso, Pombal criou, antes mesmo da fundação do Erário Régio, a Aula de Comércio em 1759 (Cunha, 2007, p. 244); daí se explica a grande afluência de homens de negócio na ocupação desses postos.

O trabalho nas administrações de correio também exigia o domínio da escrituração mercantil, afinal, envolvia a recolha de uma taxa régia e controle de receitas e despesas. Além disso, o Administrador de correio deveria ser pessoa "bem abonada e bem estabelecida", o que sugere inserção nas redes mercantis locais. ${ }^{9}$ Essa exigência de posses dava-se porque o correio deveria funcionar na casa do Administrador. Provavelmente, o "laboratório", designação dada ao local em que se recebiam e tratavam as cartas, devia estar localizado próximo ao porto ou praça de comércio, ou seja, por onde circulava a correspondência. Então, um homem de negócios/detentor de ofício fazendário era bom candidato ao posto de Administrador.

O levantamento de informações acerca dos administradores de correio não permitiu traçar, para a maioria dos casos, o envolvimento com o comércio, apesar do fato de a atividade aparecer explicitamente na documentação sobre alguns ocupantes nos ofícios postais. Contudo, foi possível rastrear, para alguma parte dos indivíduos, a ocupação de outros ofícios fazendários. Em sentido inverso, a passagem pelo correio permitia conseguir mercê de outros ofícios igualmente ligados à fazenda. Foi possível compilar dados relativos a 28 admi- 
nistradores, tanto em período prévio como posterior às suas passagens pelo correio, entre 1798 e 1825. Entre esses empregados, a ocupação de cargos de fazenda, afora os correios, é relativamente alta, de $50 \%$.

\section{Tabela 1 - Administradores com outros ofícios fazendários por capitania} $(1798-1825)^{10}$

\begin{tabular}{|l|c|r|c|c|}
\hline \multicolumn{1}{|c|}{ Capitania } & Administradores & \multicolumn{1}{c|}{$\%$} & Ofícios Fazendários & $\%$ \\
\hline Rio de Janeiro & 4 & 14 & 3 & 75 \\
\hline Pernambuco & 2 & 7 & 1 & 50 \\
\hline Ceará & 2 & 7 & 1 & 50 \\
\hline Bahia & 3 & 11 & 3 & 100 \\
\hline Pará & 3 & 11 & 1 & 33 \\
\hline Minas Gerais & 13 & 46 & 5 & 38 \\
\hline Mato Grosso & 1 & 4 & 0 & 0 \\
\hline Total & 28 & 100 & 14 & 50 \\
\hline
\end{tabular}

Outra questão a ser discutida é a permanência dessas pessoas no ofício de Administrador. Conforme apontado anteriormente, após 1770, foi comum a Coroa Portuguesa optar pela concessão precária em período trienal. Contudo, a concessão vitalícia (embora, muitas vezes, não hereditária) nunca cessou (Stumpf, 2018, p. 357). Não foi possível rastrear o período de exercício máximo atribuído aos administradores de correio. Em poucos casos encontrou-se o provimento da Junta da Fazenda, no qual normalmente se encontra tal informação. Contudo, as poucas provisões encontradas indicavam que o serviço duraria "enquanto Sua Majestade não mandar o contrário". Essa fórmula era comum para os ofícios principais da Monarquia, que eram ou "formalmente vitalícios (caso dos da Casa Real) ou o seu provimento tinha, de direito, uma duração indefinida" (Monteiro, 2012, p. 46). Mas, afora os ofícios principais, também os cargos intermédios possuíam tradição de serem doados em propriedade, a exemplo dos postos camarários (Stumpf, 2014, p. 619). Não se sabe, por meio da documentação consultada, se os ofícios de Administrador de correio foram doados em propriedade, embora o longo tempo de ocupação de alguns casos aponte para esta hipótese.

Tal foi o caso de Maximiano Francisco Duarte, Administrador do Correio de Pernambuco, que exerceria o ofício, segundo os termos da Junta da Real Fazenda, "enquanto Sua Majestade não mandar o contrário". ${ }^{11}$ Esse indivíduo 
esteve no mínimo 18 anos a serviço dos correios. ${ }^{12}$ No entanto, o ofício de Administrador de correio foi apenas um complemento associado à sua ascensão na estrutura fazendária e na conquista de mercês régias. Iniciou sua carreira como Praticante, Amanuense e Escriturário do Real Erário, em Lisboa, para depois servir como Primeiro Escriturário Contador da Junta da Fazenda de Pernambuco, cargo que exercia desde 1791. Em 1798 voluntariou-se para ocupar o lugar de Administrador de correio, sendo aceito pela Junta da Fazenda, pois possuía

as qualidades de notória honra, e verdade, e tais que pelos seus louváveis costumes tenha merecido a confiança pública, sendo além disso abonado, bem estabelecido, e morando no centro da povoação, e em lugar público; visto que o correio se há de estabelecer em sua Casa. ${ }^{13}$

Maximiano, ao escrever para a Secretaria da Marinha e Ultramar, indicou estar informado dos pormenores do trabalho, que envolviam a administração de receitas e despesas em método mercantil:

Sendo em primeiro lugar um Administrador a cargo do qual ficasse o governo do dito Correio, estabelecendo-o na boa regência que determinam as mesmas reais ordens, escriturando em método mercantil o seu rendimento dando dele conta com as necessárias clarezas, e propondo tudo quanto fosse a bem desta Administração para o progresso que dela se deve esperar $[\ldots] .^{14}$

A longa passagem deste personagem por ofícios fazendários rendeu-lhe mercês e distinção social. Em 1799, pediu à Coroa o hábito da Ordem de Cristo, listando todas as suas contribuições ao Real Serviço, inclusive como Administrador do correio. ${ }^{15}$ Conseguiu este hábito em 1804, dispensado de provanças pela Mesa de Consciência e Ordens. ${ }^{16}$ Em 1801, foi elevado à Deputado e Escrivão da Junta da Fazenda da capitania de Pernambuco. ${ }^{17}$ Logo, o ofício de Administrador de correio, em conjunto com outros cargos, contou para que Maximiano Francisco Duarte ascendesse dentro da estrutura fazendária.

Outro caso interessante é o do Administrador do correio do Pará, Antônio José Monteiro. A trajetória deste indivíduo demonstra como a ocupação fazendária podia estar ligada ao exercício do comércio, pois era negociante, e devia ter proximidade com essa rede de poder local. Além disso, tinha as posses necessárias para fornecer casa para a Administração e também dominava conhecimentos contábeis. Ao mesmo tempo que ocupava o ofício de correio, 
Monteiro também foi administrador do contrato do sal, função que exerceu até $1805 .^{18}$

Este foi outro exemplo de longo exercício, pois Monteiro ocupou o ofício entre 1802 e 1822. Inclusive, este caso permite discutir a questão da hereditariedade dos ofícios de correio e com isso fazer ligação às críticas existentes no período relativas a essa questão. Esse Administrador, alguns anos após ter sido provido, solicitou ao Conselho Ultramarino para que o ofício passasse a seu filho, Jacinto José Monteiro, após a sua morte.

O pedido, contudo, foi negado pelo Conselho Ultramarino, sob a seguinte alegação, que lembra em muito o teor do Regimento de 1770: "Estas administrações não são ofícios, de que se concedam propriedades, ou serventias vitalícias: são, e devem ser, honoráveis para melhor se servirem e acautelarem-se abusos, e prevaricações ao benefício do público e Real Erário". ${ }^{19}$ Nesse caso o abuso era compreendido como desvio de verbas e mau serviço ao bem público. Mas o fato de ter a propriedade negada não impediu que Antonio José Monteiro ocupasse o ofício por pelo menos 20 anos. Negada a propriedade, foi-lhe anuído o caráter praticamente vitalício da função.

O entendimento sobre o desempenho associado à indústria pessoal como maneira de conter abusos foi utilizado para criticar a conduta de trabalho de alguns oficiais. Esse foi o caso de Antonio Rodrigues da Silva, primeiro Administrador de correio do Rio de Janeiro. Antes de ser nomeado para este ofício, foi secretário particular do Vice-rei, $2^{\circ}$ Conde de Resende. Sua relação próxima com o Vice-rei, que também era presidente da Junta da Fazenda, pode ter contribuído para sua provisão. Ou seja, percebe-se nesse caso o peso da inserção do indivíduo em uma rede prévia, ligada à elite fazendária. Tanto que ele já ocupava ofício de fazenda, pois era Guarda-mor e Contador dos Feitos da Relação do Rio de Janeiro desde $1790,{ }^{20}$ além de Capitão da Fortificação do Castelo de São Sebastião do Rio de Janeiro desde $1795 .^{21}$

Em 1799, Antonio Rodrigues foi acusado de desvios de fundos e má escrituração de receitas. A denúncia foi feita pelo oficial de correio, Manoel Teodoro da Silva, futuro Administrador. Disse esse oficial que não o denunciou antes à Junta da Fazenda devido ao fato de o Administrador ser "criado do Vice-rei” e temia ser repreendido pela delação. O Chanceler da Relação do Rio de Janeiro então pediu para que a Junta verificasse o livro de contas e foram achados erros e emendas, além de a verba das cartas encontrar-se substancialmente diminuída. Apesar da insistência do Chanceler em expulsar o Administrador, a maioria da Junta votou o contrário. Isso revela a importância de Antonio Rodrigues da Silva estar bem relacionado com o presidente da Junta. 
A denúncia chegou às mãos do Príncipe Regente. A gravidade do erro, pelo parecer da Coroa, se dava justamente pelo fato de o Administrador ser oficial de fazenda e não cumprir sua função de bem arrecadar e registrar os valores relativos às cartas. De acordo com o parecer de D. Rodrigo de Sousa Coutinho, esses vícios deveriam ser suprimidos, "a fim de haver sempre uma fiel, pronta e verdadeira arrecadação neste importante Artigo da Real Fazenda”. Caso as culpas de Antonio Rodrigues fossem comprovadas, este, além de ser expulso do quadro dos correios, não poderia assumir mais qualquer cargo fazendário. ${ }^{22}$

As fontes não permitem saber qual foi o resultado do processo, mas tudo indica que Antonio Rodrigues cumpriu três anos de exercício, que é o tempo médio de um ofício em serventia. Mas é possível indagar se as acusações não impediram que este oficial permanecesse por maior tempo no posto, o que ocorreu com outros administradores. Manoel Moreira de Figueiredo, seu sucessor, ocupou o cargo por pelo menos seis anos, entre 1801 e $1807 .{ }^{23}$

Para o Rio de Janeiro, houve outro caso de permanência ainda maior. Manoel Teodoro da Silva, o mesmo oficial que denunciou Antonio Rodrigues por atos irresponsáveis, alguns anos depois ascendeu ao ofício de Administrador (em 1808, possivelmente) e manteve-se no cargo até sua morte em 1824. Interessante notar que esse personagem continuou como Administrador após a Independência. Isso demonstra uma continuidade na estrutura e nas formas de provisão dos últimos anos do século XVIII pela Coroa Portuguesa e a adotada pelo nascente Império do Brasil.

Manoel Teodoro foi escolhido dentro do quadro já existente de oficiais de correio, pois era ajudante desde $1798 .{ }^{24}$ Portanto, um caso de ascensão dentro do próprio órgão. Nos primeiros anos, foram selecionados indivíduos com experiência em contabilidade e escrituração mercantil, recorrendo-se a pessoas com histórico dentro das Juntas da Fazenda. Passado algum tempo, o recrutamento interno também se tornou possibilidade. Assim, os funcionários de cargos mais baixos puderam galgar posições maiores devido a sua experiência com o cotidiano do trabalho postal.

Manoel Gregório da Silva, Administrador do Correio de Pernambuco a partir de 1818, também foi outro caso de ascensão interna, pois era oficial desde 1813. Em 1816, fez requerimento para ocupar o ofício de Terceiro Escriturário da Contadoria da Junta da Fazenda. Para isso, contou com o atestado do então Administrador Maximiano Francisco Duarte, que considerou ter Manoel Gregório: 
[...] pronta e exatamente cumprido as obrigações inerentes no dito lugar, dando conta do respectivo rendimento com as clarezas precisas em semelhante expediente, pois que a sua atividade, inteligência e probidade o conduzem a servir com exação em todo que é encarregado. ${ }^{25}$

É perceptível como a ocupação de um cargo do correio poderia auxiliar na ascensão a outros postos na administração fazendária, especialmente se o candidato mantivesse boas relações com os ocupantes da elite fazendária. Lembre-se que Maximiano Duarte era deputado da Junta da Real Fazenda de Pernambuco, ou seja, um elo clientelar importante para a ascensão de Manoel Gregório. Dois anos depois, este último já era Administrador Interino do Correio-Geral de Pernambuco e Agente do Correio do Ceará, ${ }^{26}$ permanecendo nestes ofícios até 1824. Ou seja, sua inserção inicial na rede administrativa dos correios e, posteriormente, na própria Junta da Fazenda foi essencial para conseguir ascender na hierarquia dos ofícios.

Outra variante de provisão a ser investigada diz respeito à possibilidade de alienação desses ofícios por parte das Juntas da Real Fazenda. Essa foi uma prática comum para os ofícios intermédios da América Portuguesa desde 1741, que se acentuou no Período Pombalino, permanecendo em voga após a transferência da Corte em 1808 e mesmo depois da Independência (Stumpf, 2018, p. 358). Contudo, a arrematação não parece ter acontecido para a maioria dos ofícios de Administrador de correio, ou ao menos as fontes consultadas não permitem inferir essa questão.

Mas houve um caso. Trata-se do ofício de Administrador de correio das capitanias de São Pedro do Rio Grande e São Paulo. Em 1808, São Pedro do Rio Grande contava com administradores de correios em suas três principais vilas: Porto Alegre, Rio Grande e Rio Pardo. Em contrapartida, São Paulo contava com administrações na capital e na vila de Santos. Em 1817, a Coroa decidiu criar uma única administração para gerir a comunicação das duas capitanias. Foi criado o ofício de Administrador Geral, para o qual foi nomeado José Pedro Cesar. Ele deveria fazer "o sobredito estabelecimento à sua custa" pelo tempo de 10 anos. ${ }^{27}$ Em contrapartida, auferiria dos lucros do serviço. Ao fim desse tempo, o estabelecimento voltaria à Real Fazenda, sendo que nessa altura seriam criadas duas administrações de correio separadas. ${ }^{28} \mathrm{~A}$ Administração Geral, que abrangia as duas capitanias, deveria coordenar as demais administrações locais, nas vilas e cidades. Ou seja, a despeito da existência da figura do Administrador Geral, ainda existiriam os administradores locais, que seriam nomeados pelas Juntas da Fazenda e deveriam trabalhar em conjunto com José Pedro Cesar. 
Esse processo de arrematação vai de encontro ao princípio estabelecido por D. Rodrigo de Sousa Coutinho na concepção das reformas. Segundo as ideias do Ministro, o produto das cartas deveria ser sempre de administração direta e uma das fontes de lucro da Real Fazenda. Contudo, o caso da Administração de São Pedro estava de acordo com a prática comum de alienação dos ofícios intermédios do Período Joanino, pela qual a Coroa normalmente auferia lucros de forma indireta.

Essa ação não deixou de ser criticada, inclusive pelo diplomata e jornalista Hipólito José da Costa. Pautando-se em pensamento similar ao de D. Rodrigo, considerou prejudicial "estabelecer um correio entre a província extrema do Brasil, o Rio Grande do Sul, e a Capital, não por conta da Fazenda Real mas em forma de monopólio concedido a um indivíduo", pois “não há nada tão capaz de sufocar a indústria, de destruir o espírito de emulação e perpetuar os abusos, como são os monopólios" ${ }^{29} \mathrm{E}$ ainda:

O serviço dos correios [...] é de demasiada importância para que o Estado o abandone já mais a um particular [...]. É preciso, pois, pôr o correio entre o número daqueles serviços públicos, que não podem ser exercitados se não pelo Governo. ${ }^{30}$

A análise de Hipólito, pelos termos utilizados, remete à crítica feita à patrimonialização do ofício de Correio-mor em fins dos setecentos.

Portanto, os ofícios de correio eram ora associados a lógicas de Antigo Regime, ora associados a questões mais inovadoras discutidas no mesmo período. O maior argumento da reforma, preconizado por D. Rodrigo de Sousa Coutinho, era voltado para a reincorporação do ofício de Correio-mor, por ser considerado um bem da Coroa, e o usufruto do serviço exclusivo da administração régia. Contudo, questões diferentes surgem quando voltamos o olhar para a provisão dos oficiais menores, responsáveis por cuidar do trabalho rotineiro das administrações de correio implantadas nas vilas e cidade da América Portuguesa. Nesse caso, importava também a inserção desses indivíduos nas redes de poder local, e isso foi incentivado tanto pelas normas do centro como acatado nos processos de seleção feitos pelas Juntas da Real Fazenda.

\section{CONSIDERAÇÕES FINAIS}

Este artigo teve como foco a implantação dos correios na América Portuguesa após as reformas de 1798, a partir da análise do provimento dos administradores de correio. Tentou-se inserir esta questão nas discussões historiográficas 
a respeito da estrutura administrativa das Juntas da Fazenda. Conforme foi apontado, os administradores faziam parte da alçada das Juntas da Fazenda, sendo escolhidos por estes órgãos. A partir de alguns estudos de caso, foi possível perceber que muitos dos indivíduos providos já ocupavam cargos fazendários. Além disso, as fontes revelam exercícios longos, o que faz pensar em um possível teor vitalício do cargo, embora não formalmente. Essa permanência alargada também pode ser explicada, talvez, pela falta de interesse de outras pessoas em ocupar estes ofícios, ou mesmo comprá-los, haja vista o baixo ordenado atribuído a estes oficiais. Uma exceção a esse caso foi a arrematação da condução da Administração de Correio de São Pedro e São Paulo pelo período de 10 anos. Contudo, esse único caso de venalidade não foi impune de críticas por aqueles que, nesse período, acreditavam que os serviços postais deveriam ser geridos diretamente pela Coroa, haja vista a importância atribuída à organização das comunicações a distância, quer aquelas de governo, quer as particulares.

Assim, o caso específico das administrações de correio na América Portuguesa permite corroborar com as discussões relativas aos cargos e ofícios no período moderno. Embora, em fins dos setecentos, tenham se iniciado novas discussões a respeito da necessidade de conhecimentos específicos para a ocupação de determinados ofícios ("mérito"), percebe-se que a escolha dos oficiais também estava atrelada a outras questões. A ocupação prévia de ofícios fazendários não indicava somente o acúmulo de saber relacionado ao cotidiano de trabalho, que estava indubitavelmente voltado para o domínio da contabilidade. A seleção de oficiais pregressos também demonstra a busca por indivíduos que já estivessem enraizados no exercício administrativo de cada capitania, mas também que fossem bem quistos pelos habitantes daquela região (daí a importância de ser "bem abonado e bem estabelecido").

Além disso, importa enfatizar que a questão das redes clientelares e da economia moral do dom fizeram parte da lógica distributiva desses ofícios. A partir dos estudos de caso, foi possível compreender que esses indivíduos possuíam forte contato com grupos como mercadores (Antonio Monteiro, Administrador do Pará, inclusive era negociante), além de circularem pelo meio fazendário, conhecendo indivíduos de comando das Juntas da Fazenda (no caso do Rio de Janeiro, por exemplo, o primeiro Administrador era próximo do Vice-Rei). Logo, a longa permanência no ofício, vislumbrada na maioria dos casos, deve ser compreendida à luz dessas relações de clientela nas quais esses indivíduos estavam inseridos. A seleção dos administradores de correio passava pela lógica de Antigo Regime, para a qual importava a inserção nas redes de poderes locais. 


\section{REFERÊNCIAS BIBLIOGRÁFICAS}

AIDAR, Bruno. Governar a Real Fazenda: composição e dinâmica da Junta da Fazenda de São Paulo, 1765-1808. História econômica \& História de empresas. São Paulo: v. 16, n. 2, p. 163-217, 2013.

AIDAR, Bruno. Uma substituição luminosa: tributação e reforma do Antigo Regime português em D. Rodrigo de Souza Coutinho ao final do século XVIII. Nova Economia. Belo Horizonte: v. 21, n. 1, p. 137-56, 2011.

BARCELOS, Fábio Campos. A Secretaria de Estado dos Negócios da Fazenda e o Tesouro Nacional. Cadernos Mapa, Rio de Janeiro, n. 9, p. 6-197, 2014.

BICALHO, Maria Fernanda. Ascensão e queda dos Lopes de Lavre: secretários do Conselho Ultramarino. In: MONTEIRO, Rodrigo Bentes; FEITLER, Bruno; CALAINHO, Daniela Buono; FLORES, Jorge (org.). Raízes do Privilégio: mobilidade social no mundo ibérico do Antigo Regime. Rio de Janeiro: Civilização Brasileira, 2011, p. 283-304.

BICALHO, Maria Fernanda. As Câmaras Municipais no Império Português: o exemplo do Rio de Janeiro. Revista Brasileira de História, São Paulo, v. 18, n. 36, p. 251-580, 1998. Disponível em: https://bityli.com/vpIEv. Acesso em 21 dez. 2019.

COUTINHO, Rodrigo de Sousa. Textos políticos, económicos e financeiros: (1783 1811). In: SILVA, Andrée Mansuy Diniz (org.). Lisboa: Banco de Portugal, 1993.

FARIAS, Poliana Cordeiro de. A organização contábil da Junta da Real Fazenda da Bahia. In: IX Encontro estadual de história da Anpuh. Salvador, 2018. p. 1-11. Anais eletrônicos.

SOUSA, Rita Martins de. Alterações das práticas contabilísticas na Casa da Moeda de Lisboa, no século XVIII. Pecvnia, León, n. 13, p. 263-81, 2011.

CARDOSO, José Luís. Nas malhas do Império: a economia política e a política colonial de D. Rodrigo de Sousa Coutinho. In: CARDOSO, José Luís. (org.). A economia política e os dilemas do império luso-brasileiro (1790-1822). Lisboa: Comissão Nacional para as Comemorações dos Descobrimentos Portugueses, 2001. p. 63-109.

CASTRO, Pérola Maria Goldfeder de. O Império dos correios: notas de pesquisa sobre o sistema postal brasileiro no século XIX. In: I ENCONTRO DE PÓS-GRADUANDOS DA SOCIEDADE BRASILEIRA DE ESTUDOS DO OITOCENTOS, 2016. UFJF, Juiz de Fora: 2016. Anais eletrônicos.

CHAVES, Cláudia. A administração fazendária na América portuguesa: a Junta da Real Fazenda e a política fiscal ultramarina nas Minas Gerais. Almanack, Guarulhos, n. 5, p. 81-96, 2013.

COSTA, Wilma Peres; MIRANDA; Marcia Eckert. Entre os Senhores e o Império: Transformações Fiscais na Formação do Estado Brasileiro (1808-1940). Iles Imperis, Barcelona, n. 13, p. 87-115, 2010.

CUNHA, Alexandre Mendes. Minas Gerais, da capitania à província: elites políticas e a administração da fazenda em um espaço em transformação. Tese (Doutorado em 
História) - Programa de Pós Graduação em História, Universidade Federal Fluminense, Niterói, 2007. p. 334.

DIAS, Maria Odila Leite da Silva. A interiorização da metrópole e outros estudos. São Paulo: Alameda, 2005. p. 168

LOPES, José Reinaldo de Lima. Do ofício ao cargo público - a difícil transformação da burocracia prebendária em burocracia constitucional. Almanack, Guarulhos, n. 03, p. 30-35, 2012.

MACHADO, Luís Guilherme. As 'instruções' anexas ao Alvará de Criação dos Correios Marítimos para o Brasil de 1798". A Filatelia portuguesa, Lisboa, n. 6, p. 6-11, 2002. MONTEIRO, Nuno Gonçalo. O provimento dos ofícios principais na monarquia durante a dinastia de Bragança. In: STUMPF, Roberta; CHATURVEDULA, Nandini (org.). Cargos e ofícios nas monarquias ibéricas: provimento, controlo e venalidade (séculos XVII-XVIII). Lisboa: Cham, 2012. p. 39-49.

MONTEIRO, Nuno Gonçalo. O Governo da monarquia e do Império: o provimento de ofícios principais durante o período pombalino: algumas notas breves. In: SOUZA, Laura de Mello; FURTADO, Júnia Ferreira (org.). O Governo dos Povos. São Paulo: Alameda, 2009. p. 507-517.

OLIVAL, Fernanda. As ordens militares e o estado moderno: honra, mercê e venalidade em Portugal (1641-1789). Lisboa: Estar, 2001. p. 570.

SALVINO, Romulo Valle. Guerras de papel: Disputas e estratégias em torno da comunicação escrita na América portuguesa (c. 1650 - c. 1750). 2018. Tese (Doutorado em História) - Programa de Pós Graduação em História, Universidade de Brasília, Brasília, 2018. p. 427.

SLEMIAN, Andréa. Sob o Império das leis: constituição e unidade nacional na formação do Brasil (1822-1834). 2006. Tese (Doutorado em História) - Programa de Pós Graduação em História Social, Universidade de São Paulo, São Paulo, 2006. p. 338. STUMPF, Roberta. Formas de venalidade de ofícios na monarquia portuguesa do século XVIII. In: STUMPF, Roberta; CHATURVEDULA, Nandini (org.). Cargos e ofícios nas monarquias ibéricas: provimento, controlo e venalidade (séculos XVII-XVIII). Lisboa: Cham, 2012. p. 279-98.

STUMPF, Roberta. Os provimentos de ofícios: a questão da propriedade no Antigo Regime português. Topoi, Rio de Janeiro: v. 29, n. 15, p. 612-34, 2014.

STUMPF, Roberta. Ser apto para servir a Monarquia Portuguesa: profissionalização e hereditariedade. In: LEIVA, Pilar Ponce; CASTILLO, Francisco Andújar (org.). Mérito, Venalidad y Corrupción en España y América: (Siglos XVII y XVIII). Valencia: Albatros, 2016. p. 115-131.

STUMPF, Roberta. La construcción de la hacienda hispánica (siglos XVII-XIX): el gobierno de la hacienda. Espacio, Tiempo y Forma, Madrid, n. 30, p. 135-61, 2017.

STUMPF, Roberta. Administrar finanças e recrutar agentes: práticas de provimentos de ofícios no reinado joanino no Brasil (1808-1821). Almanack, Guarulhos, n. 18, p. 330-70, 2018. 
SUBTIL, José. As mudanças em curso na segunda metade do século XVIII: a ciência de Polícia e o novo perfil dos funcionários régios. In: STUMPF, Roberta; CHATURVEDULA, Nandini (org.). Cargos e ofícios nas monarquias ibéricas: provimento, controlo e venalidade (séculos XVII-XVIII). Lisboa: Cham, 2012. p. 65-80.

\section{NOTAS}

${ }^{1}$ ALVARÁ de 20 de janeiro de 1798. Coleção da Legislação Portuguesa, organizada por António Delgado Silva (1791-1801). Lisboa, 1828, 26/02/1798. Instrução para as Juntas da Fazenda do Estado do Brasil sobre correios; Arquivo do Tribunal de Contas de Lisboa (TC). Erário Régio. Livro de registo de provisões e cartas dirigidas à capitania do Rio de Janeiro. Livro 4056, 364.

${ }^{2}$ 08/03/1799. Arquivo Histórico Ultramarino. AHU_ACL_CU_010, Cx. 36, doc. 1844.

${ }^{3}$ Instruções para o correio da América. In: (Machado, 2002, p.11).

${ }^{4}$ Conforme o Artigo I do Regulamento Provisional para o novo estabelecimento do Correio (01/01/1799). Coleção da Legislação Portuguesa, organizada por António Delgado Silva (1791-1801). Lisboa, 1828, 529-331

${ }^{5}$ Diversas decisões da época aprovaram estabelecimento de correios e caminhos de terras entre Ceará, Pernambuco, Maranhão, Bahia. Decisão n. 29 de 29 de agosto de 1812, Decisão n. 22 de 28 de Junho de 1813;. Decisão n. 12, de 10 de Junho de 1814. Coleção das decisões do Governo do Brasil. Rio de Janeiro, Tipografia Nacional, 1891.

${ }^{6}$ Decisão n. 53, de 22 de novembro de 1808. Coleção das decisões do Governo do Brasil, Rio de Janeiro, Tipografia Nacional, 1891, 69-70.

7 10/04/1811. AHU_ACL_CU_017, Cx. 261, doc. 17914. O atestado dos homens de negócio, parte do requerimento, é de 16/06/1802.

${ }^{8}$ Partidas dobradas foi o método que se tentou adotar nas reformas das finanças a partir do período pombalino para o registro da contabilidade. As receitas eram discriminadas de um lado e, de outro, as despesas, para assim facilitar o cálculo do saldo (Farias, 2018, p.4). Já a Aula de Comércio foi uma instituição coordenada pela Junta de Comércio em Lisboa, que tinha como intuito a difusão de conhecimentos de contabilidade aos homens de negócio. Estas aulas, contudo, também foram responsáveis por capacitar oficiais fazendários para o exercício administrativo (Cunha, 2007, p.244).

${ }^{9}$ Instruções para o Correio da América. In Machado, “As 'Instruções' Anexas ao Alvará de Criação dos Correios Marítimos para o Brasil de 1798”, 9.

\section{${ }^{10}$ Rio de Janeiro:}

AHU_ACL_CU_017_,Cx. 173, doc.12817;

AHU_ACL_CU_017, Cx. 195, doc. 13924;

Almanaque do Rio de Janeiro para o Ano de 1825. Rio de Janeiro: Imprensa Nacional, 1825, 89. 


\section{Pernambuco:}

AHU_ACL_CU_015, Cx. 202, doc. 13807;

Arquivo do Tribunal de Contas de Portugal. TC. Erário Régio. Livro das ordens, cartas régias e provisões expedidas para Pernambuco. Livro 4236, 50.

\section{Ceará:}

AHU_ACL_CU_015, Cx. 285, doc. 19532.

\section{Bahia:}

AHU_ACL_CU_015, Cx. 203, doc. 13858;

AHU_ACL_CU_005, Cx. 113, doc. 22375;

.Arquivo Nacional do Rio de Janeiro. BR, AN, RIO, Junta da Fazenda. Bahia. Série Interior, $\mathrm{A} 1, \mathrm{IJJ}^{2} 295$.

\section{Pará:}

AHU_ACL_CU_013, Cx. 120, doc. 9238;

AHU_ACL_CU_013, cx.109; doc.8576;

AHU_ACL_CU_013, cx.136, doc.10312;

AHU_ACL_CU_013, Cx. 155, doc. 11899;

BR, AN, RIO. Negócios de Portugal. Códice 99, vol. 23, 270.

\section{Mato Grosso:}

AHU_ACL_CU_010,Cx. 36, doc. 1844.

\section{Minas Gerais:}

AHU_ACL_CU_011, Cx. 146, Doc.67;

Arquivo Público Mineiro. APM, SG-CX.57-doc.13;

APM, SG-CX.39-doc.33,

APM,SG-CX.79-doc.23;

APM,SG-CX.81-doc.34;

BR, AN, RIO. Série Interior. AA, IJJ9, 468.

Biblioteca Nacional do Rio de Janeiro. BNRJ, Manuscritos, I-27,35,006;

BNRJ, Manuscritos, I-25,07,023;

BNRJ, Manuscritos, I-26,27,067;

BNRJ, Manuscritos, I-26,30,011;

BNRJ, Manuscritos, I-27,03,038.

11 27/04/1798. AHU_ACL_CU_015, Cx. 202, doc. 13807.

${ }^{12}$ Em 1816, Maximiniano Francisco Duarte atestou, enquanto Administrador de correio, a favor de Manoel Gregório da Silva, oficial de correio, para que este último fosse provido no cargo de Terceiro Escriturário da Contadoria da Junta da Fazenda. 25/09/1816. BR, AN, RIO. Junta da Real Fazenda da capitania de Pernambuco. Código 29. códice 221, vol. 01.

${ }^{13}$ 27/04/1798. AHU_ACL_CU_015, Cx. 202, doc. 13807.

${ }^{14}$ 08/08/1798. AHU_ACL_CU_015, Cx. 203, doc. 13850.

${ }^{15}$ 09/01/1799. AHU_ACL_CU_015, Cx. 206, doc. 14039. 
${ }^{16}$ 07/06/1804.Arquivo Nacional da Torre do Tombo. ANTT. Mesa da Consciência e Ordens, Habilitações para a Ordem de Cristo, Letra M, mç. 30, n. ${ }^{\circ} 51$.

${ }^{17}$. TC. Erário Régio. Livro das ordens, cartas régias e provisões expedidas para Pernambuco, Livro 4236, 50.

${ }^{18}$ Conforme consta em seu pedido de mercê de ordem militar. 30/09/1810. AHU_ACL_ CU_013, Cx. 143, doc. 10835.

19 19/12/1805. AHU_ACL_CU_013, Cx.136, doc.10312.

${ }^{20}$ 09/06/1790. AHU_ACL_CU_017, Cx. 137, doc. 10804.

${ }^{21}$ 04/05/1795. Requerimento de Antonio Rodrigues da Silva à Rainha D. Maria I, solicitando a confirmação da carta patente no posto de capitão da Fortificação do Castelo de São Sebastião do Rio de Janeiro, que vagou por falecimento de Manoel Rodrigues da Silva. AHU_ACL_CU_017, Cx. 154, doc. 11645.

${ }^{22}$ 10/01/1800. BR, AN, RIO. Correspondência da Corte com o Vice.Reinado. Fundo 86, códice 67, volume 25 .

${ }^{23}$ Conforme é possível perceber em ofícios assinados em seu nome das seguintes datas: 04/10/1801. AHU_ACL_CU_017, Cx. 195, doc. 13924; 14/03/1807. Biblioteca Nacional do Rio de Janeiro. BNRJ, Manuscritos, I-26,31,056.

${ }^{24}$ Conforme consta da atestação que fez a favor de outro oficial de correio, de 17/09/1798. AHU_ACL_CU_017, Cx. 261, doc. 17914.

${ }_{25}$ 25/09/1816. BR, AN, RIO. Junta da Real Fazenda da capitania de Pernambuco. Código 29. códice 221, vol. 01

${ }^{26}$ Manoel Gregório da Silva aparece assinando diversos ofícios como Administrador a partir de 1818. Por exemplo, enviou, em 21/05/1818, um Plano de Correio entre Pernambuco e Bahia para o Governador de Pernambuco, Luís de Rego Barreto. Arquivo Público Estadual Jordão Emerenciano. APEJE, CG-1, F.1-5.

${ }^{27}$ Decreto de 24 de setembro de 1817. Coleção das decisões do Governo do Brasil. Rio de Janeiro: Tipografia Nacional, 1891: 60.

${ }^{28}$ Carta Régia de 24 de setembro de 1817. Rio de Janeiro, Tipografia Nacional, 1891,61-65.

${ }^{29}$ Correio Braziliense ou Armazém Literário. Impresso por L. Thompson, na oficina do correio Brasileinse, Great St. Hellens, Bishopsgate street 1818. Edição 20, 424. Disponível em: <http://memoria.bn.br/hdb/periodico.aspx>. Acesso em 03/09/2019.

${ }^{30}$ Idem, 425.

Artigo submetido em 17 de outubro de 2019.

Aprovado em 30 de março de 2020. 